\title{
Testing the Level of Compliance of International Accounting Standard IAS 38: Evidence from Bahrain
}

\author{
Mr. Mohammed Saeed Hassan ${ }^{1}$, Dr Adel M. Sarea ${ }^{2} \&$ Dr. Gagan Kukreja ${ }^{3}$ \\ ${ }^{1}$ Ministry of Finance, Manama, Kingdom of Bahrain \\ ${ }^{2}$ Department of Accounting \& Economics, College of Business and Finance, Ahlia University-Kingdom of Bahrain \\ ${ }^{3}$ Department of Accounting \& Economics, College of Business and Finance, Ahlia University-Kingdom of Bahrain \\ Correspondence: Dr Adel M. Sarea, Department of Accounting \& Economics, College of Business and Finance, Ahlia \\ University-Kingdom of Bahrain. E-mail: Adelsarea@yahoo.com
}

Received: June 21, 2019

Accepted: July 24, 2019

Online Published: July 25, 2019

doi:10.5430/afr.v8n3p136

URL: https://doi.org/10.5430/afr.v8n3p136

\begin{abstract}
This research aims to examine the level of compliance of International Accounting Standard 38 (IAS 38, intangible assets) among the listed companies of Bahrain Bourse. This paper employs the method of equal weighted disclosure index to determine if the listed firms are complying with the disclosure requirements of the IAS 38 . The required data for the year 2016 has been obtained from Bloomberg. The research found that firms have a compliance of 35.4\%. The regression analysis results showed that there is a correlation between IAS 38 disclosure and the size of audit firms, leverage, profitability and industry type. There is a lack of relationship between IAS 38 disclosure and age \& size of the company. This research serves as the basis of a future study on IAS 38 in different countries in emerging markets.
\end{abstract}

In order to assure high performance and implementation of IAS 38, all firms listed in Bahrain Bourse ought to increase the level of compliance.

Keywords: intangible assets, disclosure requirements, disclosure index, Bahrain

\section{Introduction}

IAS 38 is one of the standards of the IASB which deals with intangible assets. In the reporting process, the management of the company first convert the values of the intangible assets into a monetary unit and then report it as per the principles stipulated in IAS 38. This standard came into the existence in 1998 and has received gradual updates over the years. Since 2004, there have been no changes in IAS 38 (Gao \& Jia, 2016).

The key point of IAS 38 is that the value of each intangible asset which can be identified must be identified and mentioned using the amortization model (Deloitte, 2014). The IAS 38 outlines the different aspects of the accounting practices that are included in different organizations in the modern context of the business environment (Clavano, 2014).

(IAS 38) deals with the accounting requirements for recording the intangible assets. Some research studies stated that the adoption of IAS may impacts the decision to disclose the information as well as its financial performance. On the contrary, few other studies have also nullified the claim stating that there is no association between some firms' characteristics and the level of compliance with IAS/IFRS. The level of the compliance the firm listed in Bahrain Bourse is unknown at the current juncture and needed to study. Thus, due to the lack of studies, this study extends to further emphasis on studies by several scholars (Sarea \& Al Nesuf, 2013, Sarea \& Al Dalal, 2015, Alrawahi \& Sarea 2016, Juhmani, 2012, Budaraj \& Sarea 2015; Demir \& Bahadir, 2014) \& examines the level of compliance of listed companies with IAS 38 in order to extend on the previous studies available in the rest of the world $\&$ address the issue of compliance.

The significance of the study is that it shows the extent of limited and non-compliance behavior of financial reporting standards in the Kingdom of Bahrain. This study will inform various stakeholders about the severity of the issue of failure to comply with the accounting standards. This will also allow the government to take appropriate actions in order to increase the level of compliance by the companies. Moreover, this study can also be used by other scholars in performing further detailed analysis of the topic of compliant behavior, especially in recording intangible assets. 


\section{Literature Review}

\subsection{Objectives of Corporate Financial Reporting}

One thing that connects all the departments of organizations is the function of managing financial accounting. Financial reporting is the process of sharing the performance of each department within the organization with stakeholders in an understandable manner (Glendening, Pereira, Zhong \& Cheng, 2015). According to the International Accounting Standards Board (IASB), the objective of the corporate financial reporting is to measure, share and understand financial performance of the organization and its sub-units. Information provided by corporate financial reports allows management to undertake actions according to the financial situation of the company. According to Rashid and Alam (2015), corporate financial reporting also allows management of the organization to share performance of the company with the investors in order to attract further investment. Apart from this, corporate financial reporting also provides necessary information to external auditors of the company. As a result, such reports allow organizations to integrate all sub-functions of the company to undertake proper decisions based on the organization's current financial situation.

\subsection{Guidelines \& Implications of IASB in Organizations' Corporate Financial Reporting}

There are few disclosures that organizations must make in order to comply with the rules and the guidelines of IASB. For example, IAS38.118 C states that any kind of accumulated amount of an organization needs to be disclosed at the end of the fiscal year (Gigler, Kanodia, Sapra \& Venugopalan, 2014). Again, part D of IAS 38.118 states that line items of amortization need to be included in the financial report of the organization. The additions of the organization in terms of combining business benefits and internal development have also been mentioned in the guidelines of the IAS 38.118 as a part of specific reference. While addition of value of the organization needs to be included, the loss or impairment of organizations also needs to be disclosed by the organization according to the reference of IAS 38.118. Moreover, the carrying amount of the organization along with the amortization period also needs to be shown as per the guidelines of the IAS 38.122 section of the standard rules. Under these processes, the organizations are obliged to publish both their tangible and intangible sources of income (Glendening, Pereira, Zhong \& Cheng, 2015). Plus, the surplus of the company due to business operation for the year needs to be shown for the interest of the customers and investors in the market as per the reference guidelines of IAS 38.14.

\subsection{Importance of Corporate Financial Reporting}

In the wake of globalization, when most of the organizations are enjoying a universal market, it is important to be legally viable and undertake decisions that are ideal, as per the financial situation of the company. Ioannou and Serafeim (2017) stated that one of the main features of corporate financial reporting is that it allows the management of the organizations to review its performance, which is a vital business function. Using financial performance as a measure for the efficiency of the management, it is possible to relocate the resources of the organization in order to boost productivity and achieve optimal business benefits. Another benefit of corporate financial reporting is that it allows management to attract prospective investors to enable future expansion of the organization. However, all investors check the financial performance of the company before investing huge amounts of capital on the operations of the company, which is provided accurately by the corporate financial reporting prepared in accordance with applicable global accounting standards. In this context, Council (2015) highlighted that corporate financial reporting is for the own good of the company as it allows the organization to evaluate organizational performance and compare it to other important competitors within the market. Finally, another advantage of performing corporate financial reporting is that it allows management of the organization to keep a record that mentions use of resources in the various departments and functions of the company. This will not only allow the organization to take further decisions in the future, but it also ensures that the business can re-check and reduce the resource cost of operating the business with the available financial information.

Gao and Jia (2016) stated that in the modern world, it is always necessary for management to measure and keep a check on the financial performance of the organization as it forms the base on which the entire company structure is dependent. The corporate financial reporting practices of organizations also allow management to evaluate their performance compared to the interests and demands of the market investors that may be prospective company stakeholders in the future. Apart from that, the investors also judge the destination of the investment based on the performance of this destination. It is not possible for investors to always visit or have a representative in companies where they are interested in providing capital funds (Gigler, Kanodia, Sapra \& Venugopalan, 2014). In this case, the importance of financial reporting is huge, as it provides investors with all the necessary information regarding the company which in turn can be used by investors to measure organizational performance. 


\subsection{Limitations of Corporate Financial Reporting}

Despite having some positive benefits which impact the performance and future scope of the organization, there are still a few reasons behind companies avoiding complying with corporate financial reporting. The first disadvantage of corporate financial reporting is that it may be expensive \& the cost can go up to $\$ 2$ billion for a medium-sized business. Alam and Rashid (2014) pointed out that this is the reason why many small and medium-sized companies stay away from monetary complexities to comply with financial accounting practices.

Ahmed and Hussainey (2017) where they pointed out that companies with higher ambition and plans to expand in a foreign market, always want to be fair with their financial reporting in order to present in a transparent manner to customers and prospective investors of the business. Finally, financial reporting also makes the strategies of the organization public for a specified period of time. Davidson, Dey \& Smith (2015) stated that this works in favor of the free information available in the market. Any new entrant in the market can have free access to this information related to financial performance of successful companies.

\subsection{Reasons for the Voluntary Adaptation of the Standardized Financial Reporting of the Company}

The IFRS is a standard for financial reporting under the main body of the IASB which governs the financial reporting of the companies in the international market. The objective of this organization is to monitor the behavior of the companies in the market in terms of the compliance and their commitment towards following the international financial standards in their true spirits. Gigler, Kanodia, Sapra \& Venugopalan (2014) found out that there are few companies in the market, especially the bigger ones, who often follow these guidelines of the governing bodies without the presence of the monitoring on them because it is beneficial. This is because following these guidelines of the financial standards offers excellent benefits which provide transparency and better organizational control of the company to its top-level management. According to the survey of Das (2015), most of the leaders of large-scale companies of the market agree to the advantages of standardized reporting of their businesses and they voluntarily follow the rules and the regulations of the governing bodies like the IASB. Glendening, Pereira, Zhong \& Cheng (2015) commented that showing low performance in the company documents is a negative practice as the customers will believe that the business is not performing well and is not holding a strong position when compared to the other competitors in the market. This is the reason why most of the big industry players in the market follow financial accounting regulations that describe an organized format. Another reason for the voluntary adaption of corporate financial reporting is to work using a standard style that allows the stakeholders to compare different companies in the same marketplace.

Another reason for the voluntary adaption of the corporate financial reporting is that it provides a single language for use, where the mathematical practices of accounting describe all behaviors on the same scale. That means understanding the accounts of the other companies of the market with the use of the standardized corporate financial reports are easier to manage in a consistent manner.

\subsection{The Non-compliance and the Limited Compliance of the Company in Terms of the Corporate Financial Reporting of the Company}

Despite having few organizations who voluntarily adopt the process of the corporate financial reporting, there are other companies in the market as well, which do not follow the format for their own benefit. This is mainly seen in the case of the small businesses of the market that are looking for small gains (Gigler, Kanodia, Sapra \& Venugopalan, 2014). As discussed above, the costs of implementation and the following of an accounting standard are high \& this is problematic for the small companies to include the expenses in their limited business activities. Therefore, they follow their own method of reporting the performances of the company.

Davidson, Dey\& Smith (2015) highlighted that one of the common traits among these types of the companies is that they do not have the ambition to expand their business in the near future. The main objective is to earn a stable profit over the following years for the company. Another reason for this non-compliance often observed among small-scale companies in this part of the world, is the unusually high salaries of the business managers.

These small companies do not have a brand image to maintain as the large companies need to do. Any reduction or misstatement of their performance figures does not have the capacity to harm the company image in the market. Apart from that, as discussed before, these companies also lack the urge to grow in the near future and expand to other markets.

Although it is not mandatory for the organizations to follow the international financial reporting standard, especially small-scale companies, it is often helpful for the organizations to do this to improve their capability and have a strong ambition for the business. 
There are few companies that have been reported to show limited adherence to the rules and the regulations of the accounting standards. These companies exist throughout the world and they only follow the part of the guidelines presented by the IASB that they need to reinforce due to local laws. Consequently, their reporting structures do not match with the reporting structure of other companies of the world. The customers of their market do not get proper information from these companies that follow the limited guidelines in terms of describing the finances of the businesses. For example, these companies may follow the revised profit of the company corresponding to the IAS 36 of the guideline, but they fail to use other important standards (Gigler, Kanodia, Sapra \& Venugopalan, 2014). While at the same time the company avoids the disclosure of the generated revenue and the sudden decrease in the cost of sales, corresponding to the guidelines of the IAS 38 of the IASB. Sometimes the companies show the intangible sources of the income of the company avoiding the tangible sources. This does not match with the guidelines of the IASB. These problems are equally as important as the problem of non-compliance with the guidelines of corporate financial reporting standards because their end effect is the same. This process, followed by many small companies makes it harder for government auditing authorities to find consistency in all the financial reports, across a like Bahrain (Baker $\&$ Haslem, 2015). Various governments have undertaken strict actions in order to mitigate these challenges. However, the lack of mandate from the side of the governing bodies have allowed them to not follow these guidelines, accurately follow the international accounting standards, like the IAS 38 which provides the rules for recording the intangible assets of a business entity.

\subsection{The Level of Compliance}

The level of compliance of a company with the guidelines of the IASB depends on the different characteristics of the business such as size, leverage, company age, profitability and other important factors. As discussed above few organizations adopt the standards voluntarily while some companies avoid it in order to save the cost of operations of the business and hide the income of the top-tier managers of the company. This decision to comply with the norms of the standardized accounting process depends on the above-mentioned factors. For example, a company which is big in size will have the motto to expand the business in the future. Keeping this in mind, the management of the business should always focus on implementing standardized accounting to be feasible with other parts of the world and have international appeal. Again, a company with good experience in the market will always prefer to standardize the accounting process, so that it compares well to a business which has just emerged in the market and is in its initial phase. Venugopalan (2014) stated that the main goals of the new companies in any market are to survive and achieve a profitable position. Reporting the financial performance in a compliant manner is the secondary aim in most of these cases.

\subsection{Theoretical Framework}

Wang (2014) carried out a study where he researched the impact of intangible assets. He suggested that the investment in the intangible assets of the companies has increased multifold and has become important more than the investments in the tangible assets of businesses that have a lower growth potential. With this, the trends for mergers and acquisition of businesses have also increased compelling the companies to maintain a standard accounting reporting structure for showing that their businesses are succeeding in terms of both the tangible and the intangible asset generation performance.

Florou, Kosi \& Pope (2017) highlighted that the investment in the intangible assets of businesses is on the rise. They further evaluated that these intangible assets of companies have the potential to strengthen the future financial performance of these business entities as well. Hence, these intangible assets need to be accounted for measuring the financial performance of a company. However, there is no solution for the treatment of the intangible assets in the corporate reporting of most companies if they do not switch to following the IAS 38 reporting guidelines. Studies such as the one by Tsalavoutas \&ré \& Dionysiou (2014) found out that there exists strong non-compliance of several companies in terms of the non-disclosures of their intangible assets that hold the true value in their business models. Some of these companies also use varying standards for the reporting of the intangible assets of their businesses.

Preiato, Brown \& Tarca (2015) found out that the variation in the compliance levels of different organizations is significant, especially among the companies of the GCC countries. The overall compliance level of these companies is at $75 \%$ and overtime it has increased from $68 \%$ to $82 \%$. Therefore, there is still a significant capability to remove the non-compliance from all companies operating in the listed market, like the Bahrain Bourse. According to the study of Oulasvirta (2014), the level of financial accounting compliance of a company depends on specific firm characteristics that we have already explained, especially including the value of both tangible and intangible assets and the disclosure of this information in a transparent manner. The study of these disclosures of the financial performance of companies can be categorized into two different classes, which are the mandatory disclosure and the involuntary disclosure. 
The difference between mandatory and voluntary disclosure of financial reporting of companies is that the mandatory disclosure requires all the information of the company to be fully presented, as required and backed by national legislation and other strict principles. On the other hand, the voluntary disclosure of the company performance provides freedom to businesses and allows them to choose the elements they want to include in the financial report of the company. However, this makes it difficult to read their financial performance with an elevated level of confidence.

Most of the studies discussed above use the agency theory for describing the agency relationship and it is used as the framework for performing the research and then developing the hypothesis. Apart from that, the previous researchers also used the agency theory to justify the incentives for important managers to support the disclosure of the financial reports of the company.

The theory basically describes the issues that come when working with the interests of the shareholders where the managers (agent) of the organization make decisions on behalf of them, through the power that they have as agents. That means if there is a conflict, the agency cost would increase \& this motivates the managers of the company to report all the performance of the company.

Another theory that explains the incentives of the managers of a company for the transparent disclosure of the financial report was put forward by Bellanca and Vandernoot (2013) and is known as the signaling theory. According to this theory, companies generally tend to report comprehensive information about the company, only if the performance of the company is good. In general, companies with bad news regarding their performance not be motivated to report the financial performance which is obviously negative and represents a bleak picture. It states that the managers of a business when providing the transparent report of their company, send a signal to the shareholders that they are pursuing the wealth maximization principle for their agency. On the other hand, this signal is also received by the investors of the market for identifying a potential investment opportunity in the company, providing capital benefits. 2.9 Hypothesis Development

\section{Hypothesis 1: There is a positive association with the size of the audit firm and IAS38 disclosure}

As per the outcome of the study carried out by Radebaugh (2014), there is a significant association between the size of the external audit firm of the company and the reporting compliance. According to the justification presented in this study, large audit companies have the ability to reduce the agency cost of their services, which in turn motivates the management of their client firms to disclose all the financial report of the company as per the guidelines of IAS38 standard.

Hypothesis 2: There is a positive association with the age and IAS38 disclosure

Preiato, Brown \& Tarca (2015) stated that the age of a firm is partially related to the IAS38 disclosure ratio of the company. This is due to the fact that experienced firms are most of the time international and follow a conventional reporting structure with high agency cost. Therefore, they tend to disclose the full financial information of the organization. On the other hand, the study of Nobes and Stadler (2015) stated that the age of the operation of the company has no impact on the extent of the compliance level to the reporting standards.

Hypothesis 3: There is a positive association between the leverage of the company and the IAS38 disclosure

Tsalavoutas \&ré \& Dionysiou (2014) have argued that the companies with more debt in the capital structure of the company have a higher agency cost and hence, they have the incentive to disclose the full financial information of the business to satisfy the stakeholders.

Wang (2014) stated that leverage is one of the characteristics that influence the extent of the reporting compliance of an organization. On the other hand, arguing that many studies such as one by Glaum and others (2013) stated that leverage is insignificant when it comes to the disclosure of the compliant financial report of the company.

Hypothesis 4: There is a positive association between the firm size and IAS38 disclosure

The study on the Indian listed firms by Nobes and Stadler (2015) revealed that the firms with a bigger size and strong profitability are the ones, with the highest compliance with the standard reporting as per the IAS38.

Hypothesis 5: There is a positive association between type of industry and IAS 38 disclosure

The type of the industry might have its impact on the decision of the management to produce compliant financial reports of the organization. Glaum and others (2013) pointed out that the type of the industry has its impact on the extent of the compliance of the company in terms of the financial report of the company. It states that there are few industries where compliant financial reporting helps in the operations of the organization and hence, the industry type forces organizations to include a financial reporting process in their operations. 
Hypothesis 6: There is a positive association between profitability and IAS 38 disclosure

The association of the profitability of the company with the IAS38 is linked through the signaling theory, which states that the manager of an organization would always want to showcase the performance of the organization in order to attract the top market investors. On the other hand, the study of Glaum (2013) stated that the profitability is insignificant when it comes to its impact on the disclosure of the reports of the company.

Therefore, this study refers to the previous studies on the study and develops few of the hypotheses of the study that is related to the association of the characteristics of the firm with the extent of compliance of the company. The development of the hypothesis also considers the theories such as signaling are justifying the selection of the characteristics of the firm for the hypothesis.

\section{Research Methodology}

\subsection{Research Design}

Quantitative research method, with the descriptive analysis, is used in this research in order to evaluate the level of compliance of IAS 38 in listed companies on Bahrain Bourse. This method is commonly employed for determining the compliance level. However, a disclosure compliance checklist constructed by a previous researcher, which leads to disclosure index, was used to measure the level of disclosure compliance. Many researchers have used the disclosure index in their studies as referenced (Almujamed, Alanezi \& Alfaraih, 2017; Yiadom and Atsunyo, 2014; Budaraj \& Sarea 2015; Alrawahi \& Sarea 2015; and Demir \& Bahadir, 2014). However, the disclosure index has been modified to measure the specific IAS 38 compliance level. If a variable is in compliance with IAS 38 , a score of "1" will be assigned while a score of " 0 " is assigned when there is non-compliance with the standard.

The data has been obtained from the financial statements of companies for the year ending December 31, 2016 downloaded from bloomberg. The population of the research contains consists 43 listed firms on Bahrain Bourse in the year 2016. However, one firm has been excluded as it is suspended by Bahrain Bourse, while four listed firms are excluded due to unavailability of their annual reports. Therefore, the sample size consists of 38 listed firms as shown in the following table:

Table 1. Classification of Sample Companies by Sector

\begin{tabular}{ccccc}
\hline Sector & Population & Excluded & Sample \\
\hline & \multicolumn{2}{c}{$\begin{array}{c}\text { No. financial statement } \\
\text { available }\end{array}$} & Suspended \\
\hline Closed Companies & 2 & 1 & 0 & 1 \\
Commercial Banks & 7 & 0 & 0 & 7 \\
Hotels \& Tourism & 4 & 0 & 0 & 4 \\
Industrial & 3 & 0 & 0 & 3 \\
Insurance & 5 & 0 & 0 & 5 \\
Investment & 11 & 2 & 1 & 8 \\
Non-Bahraini & & & & 0 \\
Companies & 1 & 1 & 0 & 10 \\
Services & 10 & 0 & 0 & 38 \\
\hline Grand Total & 43 & 4 & 1 & 5 \\
\hline
\end{tabular}

\subsection{Development of Disclosure Compliance Index}

An equal-weighted disclosure index (dichotomous disclosure index), is used in this research as it is the most common method used by other researchers. This checklist provides equal weights to the items that are required to be disclosed by the standard (Demir and Bahadir, 2014). According to the findings of Marston and Shrives (1996) (cited by 
Al-Mutawa, 2010), when large number of items need to be checked for weighted and unweighted disclosure evidence, the result will be the same. So, a disclosure checklist was built by the researcher with reference to IAS 38 provision and presentation checklist published by Deloitte (2014). The disclosure index for each company is calculated by dividing the number of items reported and disclosed in the firm's annual report by the relevant items in the standard. Consistent with prior compliance research as performed by Street and Gray (2001), Al-Rawahi and Sarea (2016) and Demir and Bahadir (2014) the index employed is defined as:

Where:

$$
\boldsymbol{P C} \boldsymbol{j}=\frac{\sum \mathrm{i}=1 \mathrm{Xi}}{\boldsymbol{R} \boldsymbol{j}}
$$

PCj: compliance score for the individual firm (between 0 and 1).

Xi: level of compliance with each item of IAS 38

Rj: total number of relevant standards for each company listed on Bahrain Bourse.

As derived from the literature review, six firm characteristics were examined for their association with the level of disclosure in order to find out the extent of mandatory compliance. Table 2 illustrates the independent variables of the study and their measurements. It also shows prior studies that used similar measurement methods in the following manner:

Table 2. Independent Variables Summary

\begin{tabular}{|c|c|c|c|c|c|c|c|}
\hline Variable & Size & Leverage & Age & $\begin{array}{c}\text { Size of } \\
\text { Audit } \\
\text { Firm }\end{array}$ & Profitability & Industry & IAS 38 \\
\hline Expression & & + & & & & & \\
\hline Sign & + & & + & + & + & + & \\
\hline Measurement & $\begin{array}{l}\text { Total } \\
\text { assets } \\
\text { of } \\
\text { firms }\end{array}$ & $\begin{array}{l}\text { Ratio of } \\
\text { total } \\
\text { debts to } \\
\text { total } \\
\text { assets of } \\
\text { firms }\end{array}$ & $\begin{array}{c}\text { Date of } \\
\text { financial } \\
\text { statements } \\
\text { minus date of } \\
\text { incorporation }\end{array}$ & $\begin{array}{c}\text { Dummy } \\
\text { value (1= } \\
\text { if firm is } \\
\text { audited by } \\
\text { Big } 4,0= \\
\text { otherwise) }\end{array}$ & $\begin{array}{l}\text { Return on } \\
\text { equity } \\
\text { (ROE) of } \\
\text { the firm }\end{array}$ & $\begin{array}{c}\text { Dummy } \\
\text { values }(1= \\
\text { Financial } \\
\text { sector, } 0= \\
\text { Non-financial } \\
\text { sector })\end{array}$ & $\begin{array}{l}\text { Dummy variable } \\
\text { using a checklist } \\
1=\text { Compliance } \\
\qquad 0= \\
\text { Non-Compliance }\end{array}$ \\
\hline
\end{tabular}

\subsection{The Study Model}

The study model used this formula:

$$
y=\beta 0+\beta 1 x 1+\beta 2 x 2+\beta 3 x 3+\beta 4 x 4+\beta 5 x 5+\beta 6 x 6+\epsilon
$$

$\mathrm{y}=$ Checklist Index

$\mathrm{x} 1=$ Total Assets (Firm Size)

$\mathrm{x} 2=$ Leverage

$\mathrm{x} 3=$ Firm Age

x4 = Audit Firm Size

$\mathrm{x} 5=$ Return on Equity (Profitability)

x6 = Type of Industry

$\epsilon=$ Random error 


\section{Data Analysis and Discussion}

\subsection{Descriptive Statistics}

In this study, there are two types of data analysis performed. The first is descriptive statistical analysis of the data of listed companies. For the descriptive analysis of the data, the result is presented below:

Table 3. Descriptive Statistics for Dependent \& Independent Variables

\begin{tabular}{|c|c|c|c|c|c|c|}
\hline Variable & Min. & Max. & Mean & Std. Deviation & Skewness & Kurtosis \\
\hline \multicolumn{7}{|c|}{ Dep. Variable: } \\
\hline DCI & 0.217 & .551 & 0.354 & 10.18825 & .118 & -1.209 \\
\hline \multicolumn{7}{|c|}{ Ind. Variables: } \\
\hline Auditor & 0 & 1 & 0.974 & 0.1622 & 0 & 0 \\
\hline Age & 11 & 60 & 30.158 & 12.782 & 0.1733 & 0.816 \\
\hline Leverage & 0.06 & 0.8719 & 0.482 & 0.2703 & -0.078 & -1.297 \\
\hline Size & $7 \mathrm{E}+06$ & $1 \mathrm{E}+10$ & $1 \mathrm{E}+09$ & $3 \mathrm{E}+09$ & 2.8612 & 7.5505 \\
\hline Industry & 0 & 1 & 0.6842 & 0.4711 & 0 & 0 \\
\hline Profitability & -0.249 & 0.164 & 0.0491 & 0.1033 & -1.805 & 3.6393 \\
\hline
\end{tabular}

The above table provides the descriptive statistics of each of the characteristics of firms that provide a relationship with IAS 38 compliance. The data table shows that there are 38 observations which are employed to analyze the data, shown by $n=37$. Each one of the firm-specific characteristics has been shown in the left-hand side column of the table. The standard deviation (SD) of the auditors' variable is 0.162 (lowest) which means the spread of the data is quite limited. When comparing this with the standard deviation of age, it is found that age has a highest SD value and recorded as 12.782 .

Most of the data elements are scattered away from each other for different firms. On the other hand, size also represents a large standard deviation stating that it is also scattered and shown by the use of simple statistics. We also find that the standard deviations of other characteristics are much lower than that. The above table also shows the skewness and the kurtosis of each variable and the characteristics of the listed firm in the Kingdom of Bahrain. Another analysis of the data is done by using correlation matrix for the selected variables. The correlation analysis of the data is provided in the below table:

Table 4. The Correlation Matrix of Data

\begin{tabular}{cccccccc}
\hline & Auditor & Age & Leverage & Size & Industry & Profitability & IAS38 \\
\hline Auditor & & & & & & \\
Age & -0.149 & & & & & \\
Leverage & 0.372 & -0.242 & & & & \\
Size & $0.557^{* *}$ & -0.234 & $0.527^{*}$ & & & \\
Industry & -0.345 & 0.321 & $-0.510^{*}$ & -0.093 & & \\
Profitability & -0.130 & 0.057 & -0.111 & 0.048 & 0.341 & -0.292 \\
IAS38 & 0.293 & -0.131 & $0.447^{*}$ & 0.264 & $-0.689^{* *}$ & -0.294 \\
\hline
\end{tabular}

$* \mathrm{P}<0.05$ and $* * \mathrm{P}<0.01$ sig. level (2-tailed). Spearman correlation is shown below and from the left diagonal; Pearson correlation is shown above and from the right diagonal. From the correlation matrix, it can be seen that the auditor characteristic has the highest correlation with the size of companies listed on Bahrain Bourse. On the other hand, the case of the age characteristic is different as it shows that the highest correlation of the variable is with the industry 
where the value of $r$ is 0.321 . This means that the association of the age of the company is weak with other measured variables. However, age of company is still loosely related to the type of industry. That means that the time frame of average business of listed companies is related to the type of industry. Again, the data of the company also shows that the association of leverage variable of companies listed on the Bahrain Bourse depends on the industry as well. However, there is a negative correlation between them.

Although this study is concerned with investigating the level of compliance with IAS 38 in the Kingdom of Bahrain, the level of disclosure at 0.354 is much lower than Juhmani's (2012) study, which reported a 0.81 level of disclosure with the IFRSs. This could be due to the fact that Juhmani takes into account a number IASs and IFRSs, while this study considers only the IAS 38 disclosure. Furthermore, studies that are similar to Juhmani's, report the level of disclosure compliance with IFRSs at 0.81 (Glaum \& Street, 2003) in Germany, 0.33 in Saudi Arabia (Alsaeed, 2006), 0.70 in Kuwait (Al Muatwa, 2010) \& 0.79 in Turkey (Demir and Bahadir, 2014).

However, Tsalavoutas \&ré \& Dionysiou (2014) reported a 0.85 level of disclosure compliance with IAS 38 which is higher in comparison to the figure reported in this study. This could be due to the use of different disclosure requirements in the employed checklists of the study.

\subsection{Regression Results}

In table 5, the regression has been tested and analyzed. It has been seen that the significance has been achieved to some degree where the leverage has been found to be reasonable (0.045).

Table 5. Regression Analysis

\begin{tabular}{|c|c|c|c|c|c|}
\hline Ind. Variables & Coefficients & Std. Error & $t$-statistics & Sig. & $V I F$ \\
\hline (Constant) & 0.765 & 0.045 & 4.437 & 0 & - \\
\hline Auditor & 0.053 & 0.022 & 1.883 & 0.024 & 1.466 \\
\hline Age & -0.012 & 0.001 & -0.799 & 0.896 & 1.15 \\
\hline Leverage & 0.045 & 0 & 1.686 & 0.045 & 2.652 \\
\hline Size & 0.036 & 0.005 & 1.357 & 0.195 & 1.901 \\
\hline Industry & 0.076 & 0.012 & 2.79 & 0.014 & 2.216 \\
\hline Profitability & 0.56 & 0.009 & 1.709 & 0.032 & 1.25 \\
\hline $\mathrm{R}$-square & \multicolumn{5}{|c|}{0.419} \\
\hline $\begin{array}{l}\text { Adjusted } \\
\text { R-square }\end{array}$ & \multicolumn{5}{|c|}{0.358} \\
\hline F-statistics & \multicolumn{5}{|c|}{2.922} \\
\hline Prob. (F) & \multicolumn{5}{|c|}{$<0.01$} \\
\hline $\begin{array}{c}\text { No. of } \\
\text { Observations }\end{array}$ & \multicolumn{5}{|c|}{37} \\
\hline
\end{tabular}


Table 6. Hypotheses Results

\begin{tabular}{cccccc}
$\begin{array}{c}\text { There is a positive } \\
\text { association between IAS } \\
38 \text { disclosure and }\end{array}$ & $\mathrm{T}$ & $>1.65$ & Sig & $>0.05$ & Status \\
\hline $\begin{array}{c}\text { Auditor } \\
\text { Age }\end{array}$ & 1.883 & Yes & 0.024 & No & Accepted-Not \\
Leverage & -0.799 & No & 0.896 & Yes & Rejected \\
Size & 1.686 & Yes & 0.045 & No & Accepted \\
Industry & 1.357 & No & 0.195 & Yes & Rejected \\
Profitability & 2.79 & Yes & 0.014 & No & Accepted
\end{tabular}

According to Table 6, As per the analysis of the data collected from the companies, the level of compliance of companies listed on Bahrain Bourse is limited. Apart from that, the findings of the regression analysis in this study reveals that audit type, leverage, industry type \& profitability are related to the compliance of the IAS 38 standard. Hypothesis 1: which stated that there is a positive association with the size of the audit firm and IAS 38 disclosure has been accepted. According to the above analysis, it has been found that the value of t-test is $1.883>1.65$ and Sig value $0.024<0.05$ are all in line with a positive result. Hypothesis 2: which stated that there is a positive association with age and IAS 38 disclosure has been rejected. According to the above analysis, it has been found that the value of t-test $-0.799<1.65$ and Sig value $0.896>0.05$ are all in line with a negative result. Hypothesis 3: which stated that there is a positive association between leverage of the company and IAS 38 disclosure has been accepted. According to the above analysis, it has been found that the value of t-test $1.686>1.65$ and Sig value $0.045<0.05$ are all in line with a positive result. Hypothesis 4: which stated that there is a positive association between firm size and IAS 38 disclosure has been rejected. According to the above analysis, it has been found that the value of t-test $1.357<1.65$ and Sig value 0.195>0.05 which is in line with a negative result. Hypothesis 5: which stated that there is a positive association between the type of industry and IAS 38 disclosure has been accepted. According to the above analysis, it has been found that the value of t-test $2.79>1.65$ and Sig value $0.014<0.05$ which is in line with a positive result. Hypothesis 6: which stated that there is a positive association between profitability and IAS 38 disclosure has been accepted. According to the above analysis, it has been found that the value of t-test $1.709>1.65$ and Sig value $0.032<0.05$ which is in line with a positive result.

\section{Conclusion, Implications and Contributions}

A descriptive analysis is used to evaluate the level of compliance with IAS 38 in listed organizations on Bahrain Bourse. The results showed that the level of compliance with IAS 38 in the 38 firms was $35.4 \%$ according to measured values. The regression analysis showed that there is a significant association between IAS 38 disclosure and size of the audit firm, leverage, profitability \& industry type. However, there is no correlation with the rest of firm characteristics.

The findings of this research should be of interest to regulatory bodies in the country, such as the Central Bank of Bahrain and the Ministry of Industry, Commerce and Tourism. This would point to the need to improve monitoring and enforcement mechanisms at a national level. The study performed for year 2016 found that all listed companies were not fully complying with the IAS38 standard, but their external auditors showed in their annual report that they were in full compliance with the standards, which creates a dilemma. This supports the justification by the IASB to review the external auditors for stating that the financial statements are fully compliant with the prescribed IAS/IFRS requirements when, in fact, they are not fully compliant with them, as shown by several research studies (Cairns, 1997). Consequently, it will empower future compliance studies in the Kingdom of Bahrain and provide further insight on developing better disclosure practices, especially for intangible assets.

The study can be extended for more than one year and add more firm-specific characteristics. Even the scope of the study can be extended to GCC as this part of world has same culture and value systems. 


\section{References}

Ahmed, A. \& Hussainey, K. (2017). Is Egyptian corporate financial reporting becoming more conservative, Journal of Financial Reporting and Accounting, 15(3), 333-346. https://doi.org/10.1108/JFRA-06-2016-0049

Alam, Z. \& Rashid, K. (2014). Corporate financial reporting on the internet: A survey of websites of listed companies in Pakistan, IUP Journal of Corporate Governance, 13(3), 17-39.

Alfaraih, M. (2009). Compliance with International Financial Reporting Standards (IFRS) and the Value Relevance of Accounting Information in Emerging Stock Markets: Evidence from Kuwait (Doctoral Dissertation, Queensland University of Technology).

Ali, M., Ahmed, K. \& Henry, D. (2004). Disclosure compliance with national accounting standards by listed companies in South Asia, Accounting and Business Research, 34(3), 183-199. https://doi.org/10.1080/00014788.2004.9729963

Almujamed, H.I., Alanezi, F.S. \& Alfaraih, M.M. (2017). Are Developing Stock Markets Efficient? Evidence from Recent Kuwaiti Data. Arab Journal of Administrative Sciences, 24(1), 61-79. https://doi.org/10.34120/0430-024-001-003

Al-Mutawa, A. (2010). Disclosure Level and Compliance with IFRSs: An Empirical Investigation of Kuwaiti Companies, International Business \& Economics Research Journal, 9(5), 33-50. https://doi.org/10.19030/iber.v9i5.566

Alrawahi, F. E. \& Sarea, A. M. (2016). An investigation of the level of compliance with international accounting standards (IAS 1) by listed firms in Bahrain Bourse, International Journal of Islamic and Middle Eastern Finance and Management, 9(2), 254-276. https://doi.org/10.1108/IMEFM-07-2015-0077

Alsaeed, K. (2006). The association between firm-specific characteristics and disclosure: The case of Saudi Arabia, Managerial Auditing Journal, 21(5), 476-496. https://doi.org/10.1108/02686900610667256

Al-Shammari, B. (2011). Factors influencing the extent of mandatory compliance with international financial reporting standards: the case of Kuwaiti listed companies, Journal of International Business and Economics, 11(4), 11-31. https://doi.org/10.1016/j.intacc.2008.09.003

Al-Shammari, B., Brown, P. \& Tarca, A. (2008). An investigation of compliance with international accounting standards by listed companies in the Gulf Co-Operation Council member states, International Journal of Accounting, 43(4), 425-447.

Bahrain Business Guide (2005). Accounting, Auditing \& Taxation in Bahrain. KPMG. Retrieved April 20, 2015, from http://www.adoptifrs.org/uploads/Bahrain/Accounting\%20Auditing\%20and\%20Taxation\%20in\%20Bahrain.pdf

Baker, H. K. \& Haslem, J. A. (1973). Information Needs of Individual Investors, Journal of Accountancy, 64-69.

Bellanca, S. \& Vandernoot, J. (2013). Analysis of Belgian Public Accounting and Its Compliance with International Public Sector Accounting Standards (IPSAS) 1, 6 and 22, International Journal of Business and Management, 8(9), 122-133. https://doi.org/10.5539/ijbm.v8n9p122

Budaraj, I. A. \& Sarea, A. M. (2015). The Level of Compliance with International Accounting Standard IAS 18 by Listed Firms in Bahrain, Journal of Investment and Management, 4(5), 216-227. https://doi.org/10.11648/j.jim.20150405.22

Cairns, D. (1997). IFAC: 20 years on, World Accounting Report, 2.

Clavano, M. J. (2014). Factors That Influence the Valuation of Biological Assets and Compliance with IAS 41/PAS 41 Mandatory Disclosures by Selected Agricultural Companies in Davao Region, Proceedings of Global and Finance Research Conference 5-6 May 2014, Melbourne, Australia.

Council, F. R. (2015). Developments in Corporate Governance and Stewardship 2014. London: Financial Reporting Council.

Council, F. R. (2015). Enhancing confidence in audit: Proposed revisions to the ethical standard, auditing standards, UK corporate governance code and Guidance on audit committees. consultation. London: Financial Reporting Council.

Das, S. (2015). Timeliness of corporate financial reporting: empirical evidence from listed companies in Bangladesh, International Journal of Accounting and Finance, 5(3), 230-261. https://doi.org/10.1504/IJAF.2015.075282 
Daske, H., Hail, L., Leuz, C. \& Verdi, R. S. (2013). Adopting a Label: Heterogeneity in the Economic Consequences around IAS/IFRS Adoptions, Journal of Accounting Research, 51(3), 495-547. https://doi.org/10.1111/1475-679X.12005

Davidson, R., Dey, A. \& Smith, A. (2015). Executives "off-the-job" behavior, corporate culture \& financial reporting risk, Journal of Financial Economics, 117(1), 5-28. https://doi.org/10.1016/j.jfineco.2013.07.004

Deloitte (2014). IFRS in Your Pocket, 13th edn. Retrieved March 10, 2015, from http://www.iasplus.com/en/publications/global/ifrs-in-your-pocket/ifrs-in-your-pocket-2014

Demir, V. \& Bahadir, O. (2014). An investigation of compliance with International Financial Reporting Standards by listed companies in Turkey, Accounting and Management Information Systems, 13(1), 4-34.

Florou, A., Kosi, U. \& Pope, P. (2017). Are international accounting standards more credit relevant than domestic standards?, Accounting and Business Research, 47(1), 1-29. https://doi.org/10.1080/00014788.2016.1224968

Galani, D., Alexandridis, A. \& Stavropoulos, A. (2011). The Association between the Firm Characteristics and Corporate Mandatory Disclosure the Case of Greece, International Journal of Social, Human Science and Engineering, 5(5), 78-84.

Gao, X. \& Jia, Y. (2016). Internal control over financial reporting and the safeguarding of corporate resources: Evidence from the value of cash holdings, Contemporary Accounting Research, 33(2), 783-814. https://doi.org/10.1111/1911-3846.12164

Glaum, M. \& Street, D.L. (2003). Compliance with Disclosure Requirements of Germanys New Market: IAS Versus US GAAP, Journal of International Financial Management \& Accounting, 14(1), 64-100. https://doi.org/10.1111/1467-646X.00090

Glaum, M., Schmidt, P., Street, D. L. \& Vogel, S. (2013). Compliance with IFRS 3- and IAS 36-required disclosures across 17 European countries: company-and country-level determinants, Accounting and Business Research, 43(3), 163-204. https://doi.org/10.1080/00014788.2012.711131

Glendening, M., Pereira, R., Zhong, R. \& Cheng, C. S. A. (2015). The implications of corporate financial reporting for innovative efficiency, American Accounting Association Annual Meeting 2015: Chicago, USA.

International Accounting Standards Board (2001). International Accounting Standards Board: Framework for the preparation and presentation of financial statements. London: IASB.

International Futures (2015). Bahrain Country Profile, IFs Version 7.08. Retrieved on March 7, 2015, from http://www.ifs.du.edu/ifs/frm_CountryProfile.aspx?Country=BH

International Monetary Fund (2015). Report for Bahrain, Retrieved March 7, 2015, from http://www.imf.org/external/pubs/ft/weo/2012/01/weodata/weorept.aspx $?$ sy=2009\&ey=2015\&scsm=1\&ssd=1\&

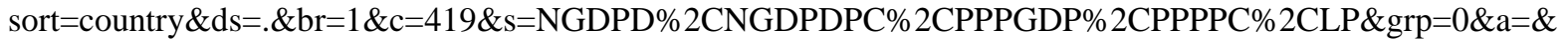
pr. $\mathrm{x}=86 \&$ pr. $\mathrm{y}=0$

Ioannou, I. \& Serafeim, G. (2017). The Consequences of Mandatory Corporate Sustainability Reporting, Harvard Business School Research Working Paper No. 11-100. Available at SSRN: https://ssrn.com/abstract=1799589 or http://dx.doi.org/10.2139/ssrn.1799589 https://doi.org/10.2139/ssrn.1799589

Judge, G. G., Griffiths, W. E., Hill, R. C. Lutkepohl, H. \& Lee, T. (1985). The Theory and Practice of Econometrics. 2nd edn. New York: John Wiley \& Sons.

Juhmani, O. I. H. (2012). Factors influencing the Extent of Corporate Compliance with IFRSs: Evidence from Companies Listed in Bahrain Stock Exchange, Journal of International Business and Economics, 12(2), 67-79.

Latifah, I.N., Asfadillah, C. \& Sukmana, R. (2012). History and Development of IFRS and AAOIFI and Their Future Challenge, Cambridge Business \& Economics Conference, June 27-28, 2012, Cambridge, UK.

Leuz, C. \& Wysocki, P. D. (2016). The economics of disclosure and financial reporting regulation: Evidence and suggestions for future research, Journal of Accounting Research, 54(2), 525-622. https://doi.org/10.1111/1475-679X.12115

Liamputtong, P. (2013). Qualitative Research Methods. 4th edn. South Melbourne, Victoria: Oxford University Press.

Marston, C. L. \& P. J. Shrives. (1996). A review of the development and use of explanatory models in financial disclosure studies, Paper presented at the 19th Annual European Accounting Association Congress, Norway. 
Nobes, C. \& Stadler, C. (2015). The qualitative characteristics of financial information \& managers accounting decisions: evidence from IFRS policy changes, Accounting and Business Research, 45(5), 572-601. https://doi.org/10.1080/00014788.2015.1044495

Oulasvirta, L. (2014). Governmental financial accounting and European harmonisation: Case study of Finland, Accounting, Economics and Law, 4(3), 237-263 https://doi.org/10.1515/ael-2014-0006

Preiato, J., Brown, P. \& Tarca, A (2015). A Comparison of Between-Country Measures of Legal Setting and Enforcement of Accounting Standards, Journal of Business Finance and Accounting, 42(1-2), 1-50. https://doi.org/10.1111/jbfa.12112

Sarea, A. M. \& Abdulla Al Dalal, Z. (2015). The level of compliance with International Financial Reporting Standards (IFRS 7) Evidence from Bahrain Bourse. World Journal of Entrepreneurship, Management and Sustainable Development, 11(3), 231-244. https://doi.org/10.1108/WJEMSD-02-2015-0009

Sarea, A. M. \& Al Nesuf, H. J. (2013). The impact of management structure and bank characteristics on the level of compliance with IAS 21: Evidence from Bahrain. International, Journal of Accounting and Taxation, 1(1), 58-68

Saunders, M. N. (2011). Research methods for business students. 5th edn. New Delhi: Pearson Education India.

Sodan, S. \& Barac, Z. (2017), The Role and Current Status of IFRS in the Completion of National Accounting Rules - Evidence from Croatia, Forthcoming in Accounting in Europe, a journal of the European Accounting Association. Available at $\quad$ SSRN: https://ssrn.com/abstract=2928710 https://doi.org/10.1080/17449480.2017.1302595

Street, D.L \& Bryant, S.M. (2000). Disclosure level and compliance with IASs: a comparison of compliance with and without U.S. listings and filings, International Journal of Accounting, 35(3), 305-32. https://doi.org/10.1016/S0020-7063(00)00060-1

Street, D.L. \& Gray, S.J. (2001). Observance of international accounting standards: factors explaining non-compliance by companies referring to the use of IAS. London: ACCA Research Monograph No.74.

Street, D.L., Gray, S.J. \& Bryant, S.M. (1999). Acceptance and observance of international accounting standards: an empirical study of companies claiming to comply with IASs, International Journal of Accounting, 34(1), 11-48. https://doi.org/10.1016/S0020-7063(99)80002-8

Sun, J., Kent, P., Qi, B. \& Wang, J. (2017). Chief financial officer demographic characteristics and fraudulent financial reporting in China, Accounting \& Finance. https://doi.org/10.1111/acfi.12286

Tai, B.Y.K., Au-Yueng, P.K., Kwok, M.G.M. \& Lau, L.W.G. (1990). Non- compliance with disclosure requirements in financial statements: the case of Hong Kong companies, International Journal of Accounting, 25(2), 99-112.

The Central Bank of Bahrain Rule Book (2013). Rule Book. Retrieved March 10, 2015, from http://www.cbb.gov.bh/assets/Consultations/Vol\%205_Financing\%20Companies_PD_2013.pdf

Tower, G., Hancock, P. \& Taplin, R. (1999). A regional study of listed companies compliance with international accounting standards, Accounting Forum, 23(3), 293-306. https://doi.org/10.1111/1467-6303.00016

Tsalavoutas, I. (2009). The adoption of IFRS by Greek listed companies: financial statement effects, level of compliance and value relevance, Doctoral dissertation, The University of Edinburgh.

Tsalavoutas, I., Paul, A. \& Dionysiou, D. (2014), Worldwide Application of IFRS 3, IAS 38 and IAS 36, Related Disclosures \& Determinants of Non-Compliance, ACCA Research Report 134. Available at SSRN: https://ssrn.com/abstract=2603572

Yiadom, E. \& Atsunyo, W. (2014). Compliance with International Financial Reporting Standards by Listed Companies in Ghana, International Journal of Business and Management, 9(10), 131-156.https://doi.org/10.5539/ijbm.v9n10p87 